\title{
Antibacterial test and toxicity of plant seed extracts: a review
}

\author{
${ }^{1}$ Ahmad Sowhini, N.S.H., ${ }^{1,2 *}$ Abdullah Sani, M.S., ${ }^{1,2}$ Has-Yun Hashim, Y.Z., \\ ${ }^{1,3}$ Othman, R., ${ }^{1,2}$ Mahamad Maifiah, M.H and ${ }^{2,3}$ Mohd Desa, M.N. \\ ${ }^{1}$ International Institute of Halal Research and Training, International Islamic University Malaysia, \\ Jalan Gombak, 53100 Kuala Lumpur, Malaysia. \\ ${ }^{2}$ Konsortium Institut Halal IPT Malaysia, Ministry of Higher Education, Block E8, Complex E, Federal \\ Government Administrative Centre, 62604 Putrajaya. \\ ${ }^{3}$ Department of Landscape Architecture, Kulliyyah of Architecture and Environmental Industry, \\ International Islamic University Malaysia, Jalan Gombak, 53100 Kuala Lumpur, Malaysia. \\ ${ }^{4}$ Department of Biomedical Science, Faculty of Medicine and Health Science, Universiti Putra \\ Malaysia, Selangor Malaysia.
}

Article history:

Received: 5 Sept 2019

Received in revised form: 6

December 2019

Accepted: 6 February 2020

Available Online: 10

February 2020

Keywords:

Seed,

Antibacterial test,

Toxicity test,

Extraction

DOI:

https://doi.org/10.26656/fr.2017.4(S1).S36

\begin{abstract}
Allah has instructed all humankind to eat permissible healthy food according to His guidance as narrated in Al-Quran. Following Maqasid as-Shari'ah, it is a Darruriyyah to ensure the safety of food as an act of protecting life. Therefore, the application of antibacterial agent on food aims to improve the consumers' health and control the herd immunity. Plant seed is a newly emerged alternative as a source of antibacterial agents. Commonly discarded, the utilisation of plant seed will not only reduce environmental waste issue but also benefited economically to many industries. This article was aimed to review the current literature on antibacterial test and toxicity of various plant seed extracts that potentially contributed to the efficacy of the seed. This review presents a comprehensive analysis of the antibacterial activity assay of the plants' seeds. It covers endpoint and descriptive methods, plant seed toxicity and application of the seed extract in food industries. This review was conducted using the various science-based platform such as Science Direct, Google Scholar, Emerald etc. The keywords 'antibacterial', 'antibacterial seed', 'seed extract' and 'toxicity seed' was used in this search.
\end{abstract}

\section{Introduction}

Halal and toyyiban consists of two elements; Halal means lawful and permissible (Syariah compliant) and toyyiban means wholesomeness (healthy, safe, nutritious, quality, hygienic preparation and other goodness-related terms). While food consumed should not only be Halal, toyyiban and free from food pathogens (Alqudsi, 2014), other consumers' products should imply the same principles too. According to surah of Al-Quran, the Al-Baqarah and An-Nahl, Allah has instructed not only His believers but also all the humankind to eat toyyiban food. For the non-believers, eating Halal is no harm at all.

"O you People! Eat of what is on earth, Halal and pure, and do not follow the footsteps of the Satan; Indeed for he is to you an open enemy" (Al-Baqarah 2:168)

"O you who believe! Eat of the good things that We have provided for you and be grateful to Allah if it is
Him that you worship" (Al-Baqarah 2:172)

"So eat of the lawful (Halal) and good food (pure wholesome, halal cattle slaughtered according to Islamic method) which Allah has provided for you. And be grateful for the Graces of Allah, if it is He Whom you worship" (An-Nahl 16:114)

All Allah's guidances as narrated in Al-Quran are purposely to protect His creatures. This is known as Maqasid as-Shari'ah (Objectives of Shari'ah Law), and it covered five primary purposes: (a) Hifzu ad-Din (protection of religion); (b) Hifzu an-Nafs (protection of life); (c) Hifzu al-'Aql (protection of intelligent); (d) Hifzu an-Nasl (protection of posterity) and; (e) Hifzu alMal (protection of property). Although Maqasid asShari'ah is personal responsibility, it is a community obligation to spread awareness and ensure the practice of protections done among their members. By doing so, the whole community will benefit a peaceful living. This 
obligation is known as Fard al-Kifayah.

Over the past centuries, there were emerging of various diseases related to foodborne pathogens, and many of them are fatal. Due to the necessity of protecting life and communities, four components of food security were established and enforced in 2002 by the Food and Agriculture Organization (FAO) of the United Nations. These four components, known as the Four Pillar of Food Security, are including (1) food availability. Enough nutritious and sufficient quality of food shall be made available for people's consumptions. Productions, distributions and exchange mechanisms shall be considered to assure this component is achievable; (2) food access. This component affected by the affordability of individuals, households or communities in accessing the food, while allocations and preferences probably based on age, gender, religion or cultural norms; (3) food utilisation. People may have accessibility to food supplies, but need to consider their ability to utilise the food. Food utilisation is mainly affected by their health status, food nutritional values, food safety (contaminant and toxic-free food), and appropriate handling of food preparation and consumption; (4) food stability. However, unforeseen factors such as war, disaster, climate change, deforestation and economic crisis may lead to a loss in food stability and then famine. Hence, risk management shall be set up to determine appropriate risk measurements and solutions (Gibson, 2012).

A food additive is a substance that is introduced into food during food preparation processes including production, processing, packaging, transportation, and storage to preserve or enhance food quality. It can extend shelf life, providing flavour or scent, improving texture or for commercial attraction. Later, the Food Additives Amendment of 1958 established in the United States' Food, Drugs and Cosmetic Act 1938. The amendment stated that food additives are required to be acknowledged as Generally Recognized as Safe (GRAS) by scientific evidence from experts before they are added into the consumers' food.

Food additives have been used worldwide since centuries ago, where their natural resources and applications are depending on the locals' preference. Up until the Industrial Revolution (IR) era, natural-sourced food additives such as spices, sugar and salt were used to preserve raw and cooked food. Later during IR, chemical food additives were introduced to the consumers without prior scientific research regarding its possible implication. Since then, the administration of food synthetic preservatives among consumers had been dramatically increasing.
The addition of natural or chemical preservatives in food is carried out to diminish microorganisms (Shee et al., 2010). Niacin, a natural additive, for instance, successfully inhibited Gram-positive bacteria such as Clostridium and Bacillus spp. in dairy products (Hansen, 1994). Similarly, chemical preservative of benzoic acid and its salts (Qi et al., 2009) had been applied to inhibit the growth of various bacteria, yeasts, and moulds (Brul and Coote, 1999). Despite its efficacy, these synthetic antibacterial agents have several significant implications on its consumers, such as allergic reaction, hypersensitivity, immunity suppression and toxicity. Besides, the emergence of drug-resistance bacteria against antibiotics and food preservatives (Russell, 1991) have led to vast anxiety. These drawbacks created awareness among consumers on the importance of having natural preservatives in their food. Besides that, the intention to produce natural preservatives will also accommodate one of the four Pillars of Food Security that required food to be safe from contamination and toxicity. Hence, ensure that food utilisation is possible to the consumers.

Plants produce a range of chemical substances as a defence mechanism from the attack of various pathogenic microorganisms by inhibiting its growth or kill it. The concentration of the antibacterial substances may vary in different tissues of the same plant (Jain et al., 2003). Despite this, plants are the best candidates as antibacterial agents due to its abundant availability as renewable resources. Plant by-products such as its seeds, roots and peels, which commonly discarded and contributed to the environmental waste, are the alternative sources of bioactive compounds for natural antibacterial agents.

Plant seed (PS) has been recognised as one of the primary sources of antibacterial agents. Antibacterials of PS origin are found to effectively reduce or inhibit pathogenic and spoilage microorganisms and provide solutions to antibiotic resistance (Sunday et al., 2016). For example, Parekh and Chanda (2011) reported on the potential of Mesua ferrea L. seed as sources of antibacterial compounds for drugs application. Additionally, edible and nonedible seeds such as papaya (Sani et al., 2017), and chia seeds (Ullah et al., 2016) were reported, to possess antibacterial properties. These findings have led to the use of essential oils (EO), flavour compounds, phenolic compounds and isothiocyanates from PS in ensuring the quality and extending shelf-life of fresh and processed fruits and vegetables (Lucera et al., 2012; Davidson et al., 2015).

Various studies of PS (Table 1) indicated the inhibitory capacity of the seeds against pathogenic 
Table 1. Antimicrobial studies on plants seeds using various extraction methods.

\begin{tabular}{|c|c|c|c|c|}
\hline $\begin{array}{c}\text { Source of } \\
\text { seeds }\end{array}$ & Extraction methods & Antibacterial activity findings & Phytochemical findings & References \\
\hline Ajowan & $\begin{array}{l}\text { Solvent extraction by } \\
\text { ethanol }\end{array}$ & $\begin{array}{l}\text { Ajowan seed extract ethanolic inhibit } \\
\text { activity of all tested bacteria which } \\
\text { are } P \text {. aeruginosa, } A \text {. lwoffii, } K \text {. } \\
\text { pneumonia, E. aerogenes and } S \text {. } \\
\text { aureus. }\end{array}$ & Thymol & $\begin{array}{l}\text { Vazirzadeh } \\
\text { et al. (2013) }\end{array}$ \\
\hline $\begin{array}{l}\text { Annona } \\
\text { squamosa }\end{array}$ & $\begin{array}{l}\text { Solvent extraction using } \\
\text { water, methanol, hexane, } \\
\text { chloroform and petroleum } \\
\text { ether. }\end{array}$ & $\begin{array}{l}\text { Water, methanol and hexane extracts } \\
\text { of seed inhibit the activity of } E \text {. coli, } \\
V . \text { cholera, S. enterica serovar Typhi, } \\
\text { S. enterica serovar Paratyphi, K. } \\
\text { pneumonia and P. mirabilis. }\end{array}$ & $\begin{array}{l}\text { TLC showed the presence of } \\
\text { Linalool, Carvone, Eugenol, Farnesol } \\
\text { and Geraniol. FTIR showed the } \\
\text { presence of alkaloids, oils, tannins, } \\
\text { phenols and flavonoids. FRAP } \\
\text { showed water extract of seed } \\
\text { contained the highest level of } \\
\text { antioxidant. }\end{array}$ & $\begin{array}{l}\text { Gowdhami } \\
\text { et al. (2014) }\end{array}$ \\
\hline
\end{tabular}

Chloroform extract of A. squamosa

Soxhlet extraction using seed inhibits the activity of E. coli, $S$. chloroform as solvent.

enterica serovar Typhi, $K$. No information.

Vikas et al. pneumonia, P. mirabilis, S. aureus (2017)

and $B$. subtillis.

Methanol extracts with the lowest

MIC among other solvents exhibit good antibacterial activity on $S$. enterica serovar Enteritidis, $V$. $\mathrm{GC} / \mathrm{MS}$ analysis of $\mathrm{MeOH}$ extract identified isothiocyanatomethyl benzene, 9-octadecenoic acid, Sani et al. (2017) vulnificus, $P$. mirabilis and B. cereus hexadecanoic acid and $\beta$-sitosterol. at $11.25 \mathrm{mg} / \mathrm{mL}$.

C. quinoa cultivar Giza1 possessed highest inhibitory activity against $L$. monocytogenes and E. coli bacteria compared to C. quinoa Sajama and cultivar Red Carina. The MIC of cultivar Gizal against $L$. monocytogenes and $E$. coli were 10 and $5 \mathrm{mg} / \mathrm{mL}$, respectively.

Cucurbita Cold maceration by using pepo variant chloroform, acetone and fastigata methanol for 24 hours.

Methanolic extract of C. pepo var. fastigata potently inhibited $B$. subtilis and $S$. aureus, while not against $E$. coli and P. aeruginosa.

Individual MIC of grapefruit, CA

The purchased grapefruit and nisin were reported to be 31.25 , seed extract (GSE) 500 to 1000 , and $250 \mathrm{ppm}$,

Grapefruit comprised of $49.49 \%$

seed extract

(DF-100,

Quinabra-

Quimica) GSE, $50 \%$ glycerin and $0.51 \%$ naringin. The extract were mixed with cinnamaldehyde (CA) and nisin. $0.05 \%$ Tween 80 were added into the mixture.

\section{respectively against $3 L$.}

monocytogenes strains. $A$ combination of 6 to 8 ppm of GSE, 15 to $20 \mathrm{ppm}$ of CA, and 5 to $6 \mathrm{ppm}$ No information. $(\mathrm{Yu}$ et al. 2019) of nisin, is an effective antibacterial
Cultivar Gizal yielded the highest mean concentration of saponin, TPC, Farajzadeh TFC and antioxidant effects among et al. (2019) the cultivars of $C$. quinoa.

There is abundant triterpenoids, phenolic compounds and tannins. Increasing concentration of methanolic extract investigated in DPPH-scavenging and hydrogen Soni and Bali (2019) peroxide assays showed increasing antioxidant activities. solution against the growth of $L$. monocytogenes on lettuce and pork loin. These concentrations are lower than their individual MIC. 
Table 1. Antimicrobial studies on plants seeds using various extraction methods (Cont.)

\begin{tabular}{|c|c|c|c|c|}
\hline $\begin{array}{c}\text { Source of } \\
\text { seeds }\end{array}$ & Extraction methods & Antibacterial activity findings & Phytochemical findings & References \\
\hline $\begin{array}{c}\text { Moringa } \\
\text { oleifera }\end{array}$ & $\begin{array}{l}\text { Maceration by using } \\
\text { deionised water, } \\
\text { chloroform, methanol, } \\
\text { hexane and ethyl acetate. }\end{array}$ & $\begin{array}{l}\text { The seed ethyl acetate extract } \\
\text { showed higher inhibition activity } \\
\text { than ampicillin in the DDT screening } \\
\text { against Proteus vulgaris, } \\
\text { Acinetobacter baylyi and } \\
\text { Pseudomonas aeruginosa. Higher } \\
\text { polarity extracts inhibited more types } \\
\text { of bacteria than the lower polarity } \\
\text { extracts. However, chloroform and } \\
\text { ethyl acetate possessed potent } \\
\text { inhibitory effect against } P \text {. vulgaris. }\end{array}$ & $\begin{array}{l}\text { All extracts showed high total } \\
\text { phenolic contents except for hexane } \\
\text { extract. There are presence of } \\
\text { abundant content of water-insoluble } \\
\text { phenolics, triterpenoids and alkaloids } \\
\text { in seed methanolic extract. While, } \\
\text { small amount of flavonoids was } \\
\text { detected. }\end{array}$ & $\begin{array}{l}\text { Ilanko et al. } \\
\text { (2019) }\end{array}$ \\
\hline
\end{tabular}

Extraction with water, methanol, $35 \%$ acetone and $60 \%$ ethanol at room temperature and boiling

Paullinia temperature of respective cupana solvents.
Alcoholic seed extracts strongly exhibited antimicrobial activity against $E$. coli, $P$. fluorescens and $B$. cereus where the size of the inhibition zone range 44 to $100 \mathrm{~mm}$.
Highest content of catechins, epicatechins and epicatechins gallate (Majhenič et were expressed by water extraction al., 2007) at room temperature.
Solvent extraction by using $70 \%$ methanol for 72 hours with constant shaking.
$10 \mathrm{mg} / \mathrm{mL}$ of the seed extract was found to be the MIC that inhibited MRSA isolates.
Phenolic compounds were found to be the richest content. Other contents (Tayel et al., of tannins, alkaloids and flavonoids 2018) were quite high.
Solvent extraction by

Lycium using 70\% methanol for

shawii 72 hours with constant shaking.
$\mathrm{MIC}$ of $8 \mathrm{mg} / \mathrm{mL}$ and $10 \mathrm{mg} / \mathrm{mL}$ inhibited each of 2 MRSA isolates, respectively.
Alkaloids content was the highest phytochemical constituent, followed by tannins, total phenolics and flavonoids compared to other seeds (Tayel et al., 2018) extracts.

\footnotetext{
Solanum $\quad 0.01 \mathrm{M}$ of $\mathrm{HCl}$ containing $0.15 \mathrm{M}$ of $\mathrm{NaCl}$ were used stramonifoliu to extract the seeds with $m$ ratio $1: 3(\mathrm{w} / \mathrm{v})$.

The seed extract successfully show inhibitory activity on Gram-positive bacteria such as $S$. aureus, B. subtilis, No information $B$. licheniformis, Xanthomonas sp. and $P$. aeruginosa.
}

(Sarnthima and Khammuang , 2012)
Sonneratia apetala (Buch Solvent extraction using -Ham) methanol.

The seeds were first extracted with light

Vitis vinifera petroleum ether for 3 hours and then methanol for 1 hour.
Seed extract inhibited the growth of Gram-positive and Gram-negative bacteria.
High content of polyphenols,

flavonoids, anthocyanins and vitamin (Hossain et

C. Also rich in antioxidant and al., 2013) antidiabetic compounds.
Gallic acid equivalent (GE) of grape seed extract (GPSE) is 209-fold richer than the grape pulp and its pericarp extract (PPE). Meanwhile, the pyrogallol equivalent (PE) of GPSE was lower than its GE, but still (Al-habib et MRSA were tested by gel diffusion, growth and respirometry studies. All strains successfully inhibited by seed crude extract, including those showing low inhibition zone. higher than PPE. GPSE containing flavonoids, but anthocyanin was not found. 
bacteria (PB) such as Escherichia coli, Salmonella enteritidis, Vibrio vulnificus, Bacillus cereus, etc. that had imposed outbreak of foodborne disease worldwide (Wilson et al., 2013). The PB can change, adapt and multiply to eliminate the suppressed environment and effectiveness of drugs, thus producing multi-antibiotics resistant isolates (MARI) that cause more harm to human. The emergence of methicillin-resistant Staphylococcus aureus (MRSA), which is a resistant MARI against various antibiotics has led the quest of new drugs from PS. The oil of black seed (Nigella sativa) had proved to render a strong inhibitory effect against MRSA in raw shellfish at retail markets in Malaysia (Othman et al., 2018).

Additionally, most PS extracts are classified as GRAS under 21 Code of Federal Regulations (Davidson et al., 2015) because they have been in our diet for many years (Calo et al., 2015) and have high $\mathrm{LD}_{50}$ values on rat or mice. The $\mathrm{LD}_{50}$ for phytosterols such as $\gamma$ tocopherol, campesterol, stigmasterol and $\beta$-sitosterol are $2220 \mathrm{mg} / \mathrm{kg}, 3000 \mathrm{mg} / \mathrm{kg}, 300 \mathrm{mg} / \mathrm{kg}$, and $3000 \mathrm{mg} / \mathrm{kg}$ respectively. A study by Upadhyay et al. (2013) reported that the lowest $\mathrm{LD}_{50}$ for a GRAS compound is $104.7 \mathrm{mg} /$ $\mathrm{kg}$ for Nigella sativa L. extract. Due to the potential of PS as antibacterial agents, this review explains the antibacterial studies of the PS.

\section{Antibacterial activity assay}

The studies of the antibacterial effect of plant metabolites on food-borne bacteria and spoilage microorganisms have been growing to cater to the demands of food quality and safety. However, the lack of method standardisation due to different extract polarity has become a limiting factor (Othman et al., 2011). The antibacterial evaluation methods fail to achieve uniformity and standardisation with the discovery of antibacterial plant metabolites from natural sources (Juneja et al., 2012). The addition of non-polar EO into emulsifier such as DMSO for complete solubility (Vladimir et al., 2011) and inactivation of some preservatives that may inhibit bacterial growth (Orth, 1993) are different from polar polyphenol extract (Osterburg et al., 2009). Furthermore, the approved method by the Clinical and Laboratory Standards Institute (CLSI) only applies to pure compound while the evaluation of antibacterial efficacy initiates from the crude extract. Thus, the method is subjected to modification (Das et al., 2010).

\subsection{Preparation of sample}

Each diluted crude extract is subjected to solvent removal prior to antibacterial assay. The removal of solvent can be done either by $\mathrm{N}_{2}$ blowing until reaching a constant weight or by rotary evaporation if non-polar extractant is used. Otherwise, the freeze-drying method is available for the polar solvent (Cano-Campos et al., 2011). Solvent removal is critical because of its bactericidal against tested bacteria (Table 2), and omission of this step may lead to false-positive result (Torres, Pandey, and Castro, 2011). The resultant dried extracts were dissolved in Dimethyl sulfoxide (DMSO) and filtered through $0.45 \mu \mathrm{m}$ cellulose membrane to remove the carried over particle from the previous extraction step. DMSO is frequently chosen because of its aprotic solvent (Harish Prashanth and Tharanathan,

Table 2. Inhibition zone of solvent on gram positive food pathogens

\begin{tabular}{|c|c|c|c|c|c|c|c|}
\hline \multirow{2}{*}{ Solvent $^{2}$} & \multicolumn{7}{|c|}{ Total inhibition ${ }^{1}, \mathrm{~mm}$} \\
\hline & S. aureus & B. cereus & L. monocytogenes & C. diphtheria & C. perfringens & S. pneumoniae & B. subtilis \\
\hline Hexane & $\mathrm{Na}$ & $\mathrm{Na}$ & $\mathrm{Na}$ & na & na & na & na \\
\hline $\mathrm{PE}$ & $\mathrm{Na}$ & na & $\mathrm{Na}$ & na & na & na & na \\
\hline $\mathrm{DE}$ & $\mathrm{Na}$ & na & $\mathrm{Na}$ & $1.82 \pm 0.43_{\mathrm{D}}^{\mathrm{a}}$ & $1.59 \pm 0.53^{\mathrm{a}}{ }_{\mathrm{C}}$ & na & na \\
\hline CHCL3 & $3.62 \pm 0.93^{\mathrm{b}}{ }_{\mathrm{C}}$ & $6.01 \pm 2.95^{\mathrm{c}}{ }_{\mathrm{B}}$ & $4.97 \pm 1.32^{\mathrm{c}}{ }_{\mathrm{A}}$ & na & $7.69 \pm 1.18^{c}{ }_{B}$ & $7.73 \pm 1.77^{\mathrm{c}}{ }_{\mathrm{B}}$ & $7.31 \pm 0.99^{c}{ }_{B}$ \\
\hline DCM & $1.81 \pm 0.76^{\mathrm{a}}{ }_{\mathrm{D}}$ & $1.58 \pm 0.30^{\mathrm{a}}{ }_{\mathrm{C}}$ & $\mathrm{Na}$ & $7.34 \pm 1.18^{\mathrm{c}}{ }_{\mathrm{B}}$ & $1.58 \pm 0.82^{\mathrm{a}}{ }_{\mathrm{C}}$ & $1.11 \pm 0.56^{\mathrm{a}}{ }_{\mathrm{C}}$ & $2.15 \pm 0.05_{\mathrm{D}}^{\mathrm{a}}$ \\
\hline Acetone & $2.81 \pm 1.0^{\mathrm{a}} \mathrm{c}_{\mathrm{D}}$ & $4.34 \pm 1.58^{\mathrm{c}}{ }_{\mathrm{BC}}$ & $3.45 \pm 0.79^{\mathrm{b}}{ }_{\mathrm{AB}}$ & $3.69 \pm 2.05^{\mathrm{b}} \mathrm{CD}$ & $5.49 \pm 0.78^{\mathrm{c}}{ }_{\mathrm{B}}$ & $5.73 \pm 1.64^{\mathrm{c}}{ }_{\mathrm{B}}$ & $3.87 \pm 1.31_{\mathrm{CD}}^{\mathrm{b}}$ \\
\hline $\mathrm{EtOH}$ & $6.65 \pm 0.65^{\mathrm{c}}{ }_{\mathrm{B}}$ & $6.65 \pm 0.63^{c}{ }_{B}$ & $3.43 \pm 0.57^{\mathrm{b}}{ }_{\mathrm{AB}}$ & $6.27 \pm 1.08^{\mathrm{c}}{ }_{\mathrm{BC}}$ & $6.27 \pm 1.76^{\mathrm{c}}{ }_{\mathrm{B}}$ & $7.09 \pm 1.87^{\mathrm{c}}$ & $6.69 \pm 2.93_{\mathrm{BC}}^{\mathrm{c}}$ \\
\hline $\mathrm{MeOH}$ & $1.31 \pm 0.28_{\mathrm{D}}^{\mathrm{a}}$ & $2.03 \pm 1.36^{\mathrm{a}}{ }_{\mathrm{C}}$ & $2.49 \pm 1.50^{\mathrm{a}}{ }_{\mathrm{B}}$ & $3.73 \pm 0.36^{\mathrm{b}} \mathrm{CD}$ & $1.62 \pm 0.88^{\mathrm{a}}$ & $1.31 \pm 0.27^{\mathrm{a}}$ & $2.85 \pm 0.61^{\mathrm{a}} \mathrm{D}$ \\
\hline $\mathrm{ACN}$ & $1.78 \pm 0.77_{\mathrm{D}}^{\mathrm{a}}$ & $3.72 \pm 0.29^{b}{ }_{B C}$ & $1.28 \pm 0.61^{\mathrm{a}}{ }_{\mathrm{B}}$ & $3.01 \pm 0.18_{\mathrm{D}}^{\mathrm{b}}$ & $1.94 \pm 0.78^{\mathrm{a}} \mathrm{C}$ & $5.33 \pm 0.82^{\mathrm{c}}{ }_{\mathrm{B}}$ & $6.09 \pm 0.47^{\mathrm{c}}{ }_{\mathrm{BCD}}$ \\
\hline Water & $\mathrm{Na}$ & na & na & na & na & na & na \\
\hline DMSO & $\mathrm{Na}$ & na & na & na & na & na & na \\
\hline $\mathrm{TCH}$ & $27.83 \pm 0.29^{c}{ }_{A}$ & $15.00 \pm 0.50_{\mathrm{A}}^{\mathrm{c}}$ & na & $12.44 \pm 1.61_{\mathrm{A}}^{\mathrm{c}}$ & $14.78 \pm 0.37_{\mathrm{A}}^{\mathrm{c}}$ & $11.61 \pm 0.85^{\mathrm{c}}{ }_{\mathrm{A}}$ & $14.35 \pm 0.33_{\mathrm{A}}^{\mathrm{c}}$ \\
\hline
\end{tabular}

${ }^{1}$ Means with different subscript capital letter within column are significantly difference $(\mathrm{p}<0.05)$. ${ }^{2} \mathrm{PE}-$ petroleum ether, DEdiethyl ether, CHCL3-chloroform, DCM- dichloromethane, EtOH - ethanol, MeOH - methanol, ACN - acetonitrile, DMSOdimethyl sulphoxide, TCH - tetracycline hydrochloride $(10 \mathrm{mg} / \mathrm{mL}) .{ }^{3}$ na - No antibacterial activity (inhibition zone of sample $<$

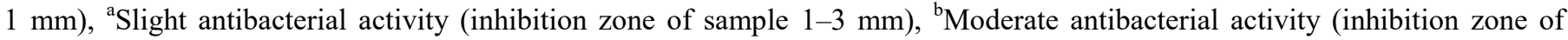
sample 3-4 mm), ${ }^{\mathrm{C} C l e a r}$ antibacterial activity (inhibition zone of sample 4-10 mm) (Rauha et al., 2000). 
2007), which can stabilise the emulsion of EO (Turgis et $a l ., 2012)$ and do not inhibit bacterial growth (Othman et al., 2011). Wilson et al. (2002) utilised DMSO in oily extract dilution. Often, for extract stabilisation purpose, the plant extract is stored under low temperature (Cseke et al., 2006). However, the solubility of extract in a solvent is affected by temperature causing precipitation at low temperature for the reconstituted dried extract with DMSO; thus, Kothari (2014) suggested to perform bioassay when extract reaching room temperature.

\subsection{Preparation of inoculum}

The inoculums are prepared by transferring a loopful of cells from the bacterial cultures into sterile tryptone soy broths (TSB). These cultures can be maintained lower than $4^{\circ} \mathrm{C}$ and must be subcultured every fortnight. $1 \mathrm{~mm}$ glass beads can be used to assist in breaking up small clumps of organisms and incubated between $4-16$ hrs at $37 \pm 2^{\circ} \mathrm{C}$ to achieve inoculum containing $10^{6}-10^{8}$ CFU/mL (Biehle et al., 1994). Recommendation against inoculum concentration exceeds this value is to avoid selection of resistant mutants (CLSI, 2012). The standardized bacterial colony numbers can be achieved through: (1) the establishment of bacterial growth within $24 \mathrm{hrs}$ and corresponding turbidity at $600 \mathrm{~nm}\left(\mathrm{OD}_{600}\right)$ (Othman et al., 2011) and (2) Comparing bacterial turbidity against $0.5 \mathrm{McFarland}$ standard, which is equal to $10^{6}-10^{8}$ colony-forming unit $(\mathrm{CFU}) / \mathrm{mL}$ (Vazirzadeh et al., 2013) have been practised as standard methods prior to antibacterial evaluation. The former is frequently chosen due to its viable cell count, compared to the latter, which has inconsistency of turbidity value (Othman et al., 2011). Conversely, since the exponential growth of bacteria is achieved at $10^{6}-10^{8} \mathrm{CFU} / \mathrm{mL}$, the establishment of a calibration curve using McFarland standards may give acceptable turbidity range and hence reduces the error of non-viable bacterial cell.

The McFarland standards are designed for estimating concentrations of gram-negative bacteria such as E. coli. because it has no incubation time, or it does not need any equipment to estimate bacterial numbers. Generally, the standards are labelled from 0.5 through 10 and are filled with suspensions of barium salts. Latex bead suspensions are also available, which extend the shelf life of the material. The standards may be made in the lab by preparing a $1 \%$ solution of anhydrous $\mathrm{BaCl}_{2}$ and a $1 \%$ solution of $\mathrm{H}_{2} \mathrm{SO}_{4}$ through mixing them in proportions. They should be stored in the dark, in a tightly sealed container at $20-25^{\circ} \mathrm{C}$, and should be stable for approximately six months. However, it is inappropriate for fastidious bacterial growth.

On the other hand, for $\mathrm{OD}_{600}$, few critical steps should be emphasized: (1) there is a need to calibrate the serial dilution of bacterial suspensions against their $\mathrm{CFU} /$ $\mathrm{mL}$, (2) $\mathrm{OD}_{600}$ and its respective $\mathrm{CFU} / \mathrm{mL}$ is exclusive for individual bacterial growth, and (3) recalibrate the bacterial suspension if the spectrophotometer's lamp is replaced.

\subsection{Antibacterial activity assay}

There are few techniques employed in evaluating the antibacterial activity of fruit seeds extracts. These techniques are categorised as endpoint methods and descriptive methods. Vigil et al. (2005) concluded that both endpoint and descriptive methods should be employed for the antibacterial of potential bioactive compounds. Generally, endpoint methods include agar diffusion test (ADT), minimum inhibitory concentration (MIC) and minimum bactericidal concentration (MBC). Bacterial growth curve and time-killed curve are the descriptive methods for antibacterial assay.

\subsubsection{Endpoint methods}

Endpoint method in the antimicrobial assay is a determination of the final result, which a manipulated variable influenced the bacterial growth. Endpoint method emphasises on the reason why bacterial growth resulted in a certain way due to by one or more manipulated variables. For example, what are the sample concentrations that inhibited or killed the bacterial growth? What is the minimum concentration that does so? How many percentages of bacteria that are actually be killed? These questions can be solved by conducting ADT, MIC and MBC assays. Also, automated instruments are the latest trending in determining bacterial sensitivity. In these assays, a range of concentrations of the sample is tested against bacteria of interest. Generally, the test outcome has two probabilities; (1) inhibited or not inhibited in ADT or (2) positive or negative turbidity value in MIC and MBC. The value is the difference of turbidity measured before and after $24 \mathrm{hrs}$ incubation, of the inoculated broth added with extracts. However, the endpoint method is a preliminary stage, and further research is recommended by conducting descriptive method to support results reliability.

\subsubsection{Diffusion test (DT)}

DT is a qualitative method to evaluate the antibacterial properties of crude or purified extract, as a single form or in combination with other antibiotics (Roccaro et al., 2004) against aerobic bacteria. DT consists of two methods: disc (DDT) and agar well (AWDT) techniques. Of these, the latter produces more precise data (Cattelan et al., 2013) and has a low possibility of rendering false negative result (Vigil et al., 
2005). The DDT can be performed through pour plate (PPDD) and spread plate (SPDD) techniques.

In principle, for DDT, an aliquot of $100 \mu \mathrm{L}$ inoculum was mixed with molten soft agar (for PPDD) or spread on sterilised plate agar (for SPDD). Sterile paper discs (6 $\mathrm{mm}$ diameter) containing extract solution pipetted is then placed on them. For PPDD, the molten soft agar and inoculum mixture is poured on to the layer of Mueller-Hinton agar (MHA) to ensure even distribution of bacteria (Othman et al., 2011). The incubation was done at $37 \pm 2{ }^{\circ} \mathrm{C}$ for $24 \mathrm{hrs}$.

Likewise, AWDT involves the pipetting of extract solution into a borer-punched well in the solidified mixture of seeded bacteria and agar. The plate agars were then incubated at $37 \pm 2^{\circ} \mathrm{C}$ for $24 \mathrm{hrs}$. The extract diffuses through agar, resulting in concentrated gradient. The degree of inhibition is indicated by a zone of growth around the disk and well, depending on the rate of diffusion of the compound and the cell growth. Therefore, the extract should not be too hydrophobic or lipophilic to avoid non-diffusion and to cater for the need for further investigation of antibacterial efficacy especially when dealing with non-polar extract (Ríos and Recio, 2005). The bacteria tested should grow rapidly and uniformly because of slow bacteria growth results in larger inhibition zone and vice versa. Bacterial growth inhibition was determined by the diameter of the inhibition zones $(\mathrm{mm})$ using calliper after subtracting 6 $\mathrm{mm}$ of paper disc diameter. DMSO and known antibiotics were used as negative and positive controls, respectively.

The determination of the extracts inhibitory strength is subjective between researchers. It depends on the main objective and application of the research, i.e. food industry, pharmaceuticals industry and many more. Piddock (1990) termed the bacterial inhibition activities as (1) susceptible when the zone is $>30-35 \mathrm{~mm}$ in diameter, (2) intermediate with a zone of $20-30 \mathrm{~mm}$, (3) resistance with the zone of $<15-20 \mathrm{~mm}$, which are applied for pharmaceutical purposes. Due to acid digestion in the stomach, the pure antibiotic will be metabolised and undergo additional reaction. Other agar diffusion assay reported for plant's antibacterial activity classifications are $0-0.3 \mathrm{~mm}, 0.3-0.7 \mathrm{~mm}$, and $0.7-$ $1.0 \mathrm{~mm}$ zone of inhibition, which indicates low, medium, and high activity, respectively (Eloff, 2004).

However, the method used by Rauha et al. (2000) to define the susceptibility of bacteria for food is through crude extract applied against bacteria. The criteria used are: no antibacterial activity when the zone is $<1 \mathrm{~mm}$, slight antibacterial activity when the zone is between $1-$ $3 \mathrm{~mm}$, moderate antibacterial activity when the zone is between $3-4 \mathrm{~mm}$, clear antibacterial activity when the zone is between $4-10 \mathrm{~mm}$, and strong antibacterial activity when the zone is $>10 \mathrm{~mm}$.

\subsubsection{Minimum inhibitory concentration and Minimum bactericidal concentration}

Until recently most in vitro susceptibility testing was performed by DT. However, DT is appropriate only as a preliminary test and could not tell the exact concentration of extract needed to achieve a therapeutic result (Klancnik et al., 2010). MIC test is introduced to overcome the above limitation. The MIC can be done by agar or broth dilution methods. However, Klancnik et al. (2010) found that the latter was the most accurate and faster way of assessing the antibacterial effect. It also applies to investigate the inhibitory effect of low polarity extract on bacterial growth kinetic (Othman et al., 2011). By conducting MIC evaluation, seed extract with the lowest concentration can be identified as a potential economic antibacterial agent against pathogenic bacteria (Rub and Sasikumar, 2016).

The MIC number is the lowest concentration of drug that inhibits the growth of the pathogen, while MBC is the lowest concentration that kills more than $90 \%$ of the initial pathogen population. Thus MBC is also known as $\mathrm{MIC}_{90}$ (Si et al., 2006), that is, a dilution greater than MIC since the former's ability is limited to the inhibition of the growth of pathogens. The MIC determination can be done by measuring the turbidity. However, MBC determination shall be done by cultivating the MIC and higher concentrations of extract, together with the positive control, onto solid mediums of nutrient agar. The nutrient agars are incubated at $37 \pm 2^{\circ} \mathrm{C}$ for $24 \mathrm{hrs}$.

Agar dilution method had been used before the broth dilution method came into the board. Extracts are prepared in two-fold dilution and mixed with agar to give a range of extract concentration, seeded with inoculum at $10^{6} \mathrm{CFU}$ and incubated for $24 \mathrm{hrs}$ (Gutierrez et al., 2009). The cell is counted (Wiegand et al., 2008) and MIC is defined as the lowest extract concentration yielded no bacterial growth on the agar (López et al., 2011).

Broth dilution method is evaluated through macroscopic evaluation or turbidity measurements. Both methods entail the dilution of extract in 96-wells microplate or tube, which is known as micro- or macrodilution. Turbidity evaluation involves the dilution of extracts into broth medium to obtain two-fold serial dilution. The serial concentrations of EO were filled into 96-well microplate with a volume of $90 \mu \mathrm{L}$. Each well was then inoculated with $10 \mu \mathrm{L}$ of a pathogenic strain at a concentration of $10^{6} \mathrm{CFU} / \mathrm{mL}$. The microplate was 
incubated aerobically for $24 \mathrm{hrs}$ at $37^{\circ} \mathrm{C}$. A sterile broth medium incubated under the same condition was used as a blank. A broth medium incubated with a target bacterium (without an antibacterial agent) was used as a positive control of growth while a mixture of sterilised broth and extract was used as a negative control.

For macroscopic evaluation, sterile discs are soaked into each well and placed onto an inoculated agar plate, where the lowest concentration that shows visible inhibition zone is considered as MIC after comparison with control disc (Iturriaga et al., 2012). Furthermore, a comparison between positive control and extract dilutions in the wells determines the MIC, whereby the lowest concentration with the lack of visible growth is considered as MIC (Lv et al., 2011). Addition of colour indicators such as resazurin (Vladimir et al., 2011), TTC (2,3,5-triphenyl tetrazolium chloride) or INT (2-piodophenyl-3-p- nitrophenyl-5-phenyl tetrazolium chloride) to indicate the viability of aerobic bacteria has helped in determining the MIC (Klancnik et al., 2010). Otherwise, to reduce uncertainty due to subjectivity from macroscopic evaluation, the turbidity evaluation is sought by measuring optical density at $600 \mathrm{~nm}$ before $\left(\mathrm{T}_{0}\right)$ and after the 24 -hour incubation $\left(\mathrm{T}_{24}\right)$ at $37^{\circ} \mathrm{C}$. The MIC is defined as the lowest concentration of antibacterial agent showing a complete growth inhibition of the tested bacterial strain. It is related to a different absorbance of zero, that is, $\mathrm{T}_{24}-\mathrm{T}_{0}=0$, i.e. $\mathrm{T}_{24}=\mathrm{T}_{0}$ or $\mathrm{T}_{24}<\mathrm{T}_{0}$ (Turgis et al., 2012).

To confirm the MIC and MBC values, an aliquot of $10 \mu \mathrm{L}$ from a test well is collected from those tubes that did not show any growth and pipetted onto sterile agar. Control plates containing agar alone are also streaked with the respective organisms. All plates are incubated at $37^{\circ} \mathrm{C}$ for $24 \mathrm{hrs}$, and the concentration at which no visible growth is seen is noted as the $\mathrm{MBC}$ while for MIC, the lower concentration than MBC is selected (Adejuwon et al., 2011).

Boulekbache-Makhlouf et al. (2013) classified plant extracts on the basis of their MIC values: strong inhibition $=$ MIC $<500 \mu \mathrm{g} / \mathrm{mL}$; moderate inhibition = $600 \mu \mathrm{g} / \mathrm{mL}<\mathrm{MIC}<1500 \mu \mathrm{g} / \mathrm{mL}$, and low inhibition $=$ MIC > $1600 \mu \mathrm{g} / \mathrm{mL}$. However, fractionated plant metabolites render lower MIC due to purified extract (McGaw et al., 2002) and elimination of antagonistic antibacterial effect from other components of the complex crude extract composition (Broniatowski et al., 2015).

\subsubsection{Automated instruments}

Recently, automated instruments for identification and testing susceptibility of potential antibacterial agents have been introduced. These instruments categorised as densitometer, redox meter, gradient methods and fluorometers are tabulated in Table 3 . In some studies, these instruments have been compared in determining their efficiency in the antibacterial susceptibility testing (Fader et al., 2013). Redox meter was compared to the conventional methods as reference method and reported to have approximately 95\% agreement for genus-level identification (Carroll et al., 2006). Snyder, Munier, and Johnson (2008) reported that fluorometer able to detect challenging isolates correctly compared to redox meter. However, these two instruments have a reasonable correlation and agreement level of more than $95 \%$.

Although automated instruments can produce faster results, allow standardisation, a lesser time required for data gathering and analysis, yet the employment of these modern instruments may be the main factor leading to the high cost in testing antibacterial activity. Plus, the built-in systems may be too restrictive and limiting the modification of experimental designs for some scientists. While the panels and cards are pre-formatted by the manufacturer, custom-made of these components is way too expensive.

\subsubsection{Descriptive methods}

The concentration of extract required to inhibit pathogens is determined through MIC and MBC tests. However, these methods provide little information concerning the effects of an antibacterial that are below the MIC. Certain antibacterial extracts may still cause an increase lag phase, reduced growth rate or even initial lethality followed by growth. In food research, total inhibition of spoilage pathogens is not always required as an increased lag phase is enough to protect the consumers (Vigil et al., 2005). Therefore, the descriptive method is used to describe the effectiveness of MIC and MBC of the sample.

In contrast with the endpoint method, the descriptive method can be related to which responded variable is the main concern in identifying and describing graph trends in the bacterial curve. The manipulated variable is not really taken into the discussion. The finding of the descriptive method can be used to validate the final result of the endpoint method. In the antimicrobial assay, the descriptive method involves bacterial growth curve as well as the time-kill curve. It explains the observable conditions, quantitatively and/or qualitatively, of the bacteria growth and inhibition time instead of why they happened. Based on the constructed growth curve, lag phase, log phase and growth rate can be determined. Time-kill curve explains the optimum time taken for the selected sample concentration to kill bacteria of interest. 

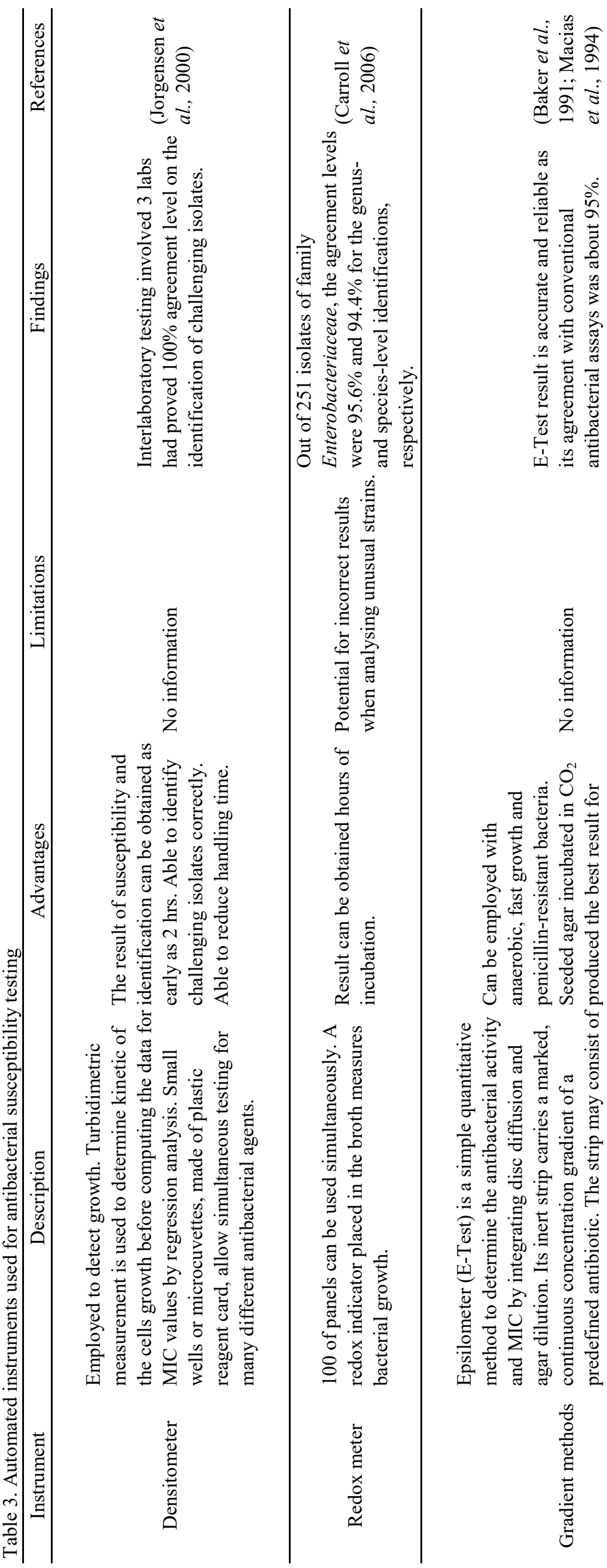

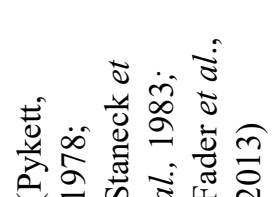

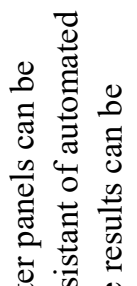

过

ते

忞 $\frac{0}{0}$

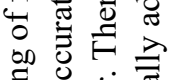

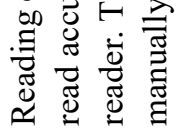

큘

苛

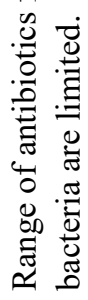

귷

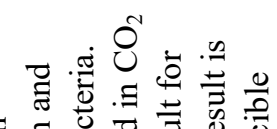

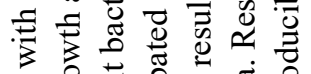

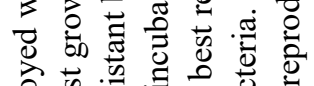

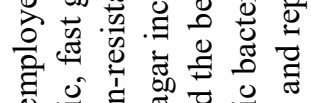

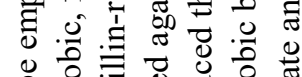

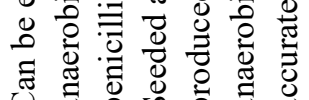

8 वी

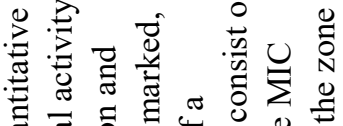

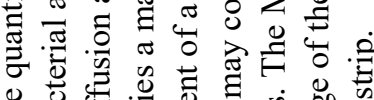

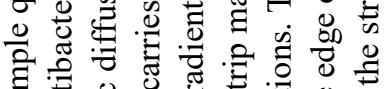

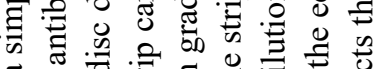

क ส

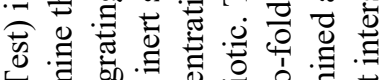

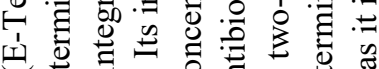

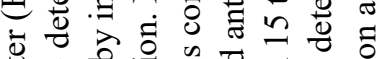

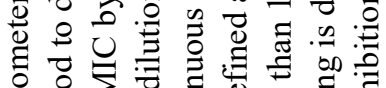

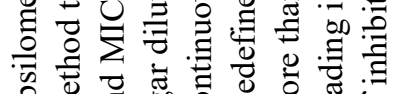

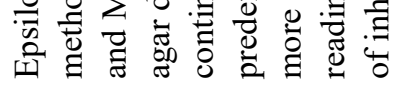

品

产

帘

这芯

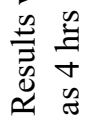

.

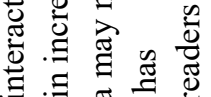

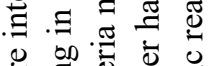

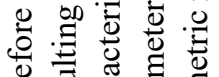

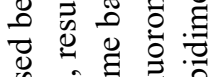

ठै की

Ð

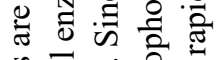

ठै.

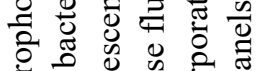

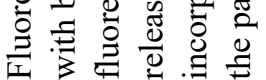

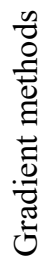

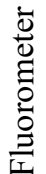




\subsubsection{Time-killed curve}

The inhibition curve method is also called the timekilled curve, and it has been used to study the effect of antibacterial lower than MIC. A mixture of broth media and the extract is prepared in which the concentration of the extract was at MIC and lower than MIC values. Positive control of known antibacterial was prepared as well. The bacteria (with concentration of $10^{6} \mathrm{CFU} / \mathrm{mL}$ ) were added into the broth and extract mixture and incubated at $37^{\circ} \mathrm{C}$ for $48 \mathrm{hrs}$ for the determination of the colonies at $0,2,4,8,12,24$, and $48 \mathrm{hrs}$ by spread plating on MHA (Ji et al., 2008). Both general and specific medium can be used for the spread plate method (Kanatt et al., 2010).

Another approach for the time-kill curves test is by measuring the increase of turbidity using spectrophotometer. By applying the time-kill curve test, several responses are retrieved, such as stationary-phase growth level suppression, lag-phase increase, decrease in log-phase growth rate, and lethality.

\subsubsection{Lag phase, log phase and growth rate}

The microbial lag phase reflects the time required for cells to adapt to a new environment and start duplicating. The lag phase depends on many factors, and all physical or chemical conditions of the growth environment considerably extend the lag phase and increase its variability (Aguirre et al., 2013). More extended lag phase indicates a more prolonged time taken for a food to be spoiled by foodborne pathogens. Lag phase identification is through (a) the intercept of initial log phase and constant growth rate line (Hall et al., 2014) or (b) intercept of exponential growth line to the x-axis (Carey, 2009).

A log phase is an exponential growth phase, where cell division proceeds at a constant rate (Rolfe et al., 2012). The specific growth rate is maintained when the exponential growth rate continually increases, which are significantly affected by the presence of a high concentration of nutrients. Based on the log phase, the specific growth rate $(\mu)$ can be calculated according to Monod equation as expressed below, where, $\mu_{\max }$ is maximum specific growth rate $\left(\right.$ time $\left.^{-1}\right), \mathrm{S}$ is the concentration of substrate in a solution (mass/volume), and $\mathrm{K}_{\mathrm{S}}$ is the half velocity constant (mass/volume):

$$
\mu=\left(\mu_{\max }\right)\left(\frac{S}{K_{S}-S}\right)
$$

Lower $\mu$ indicates lower growth of foodborne pathogens and thus, reduces the time of food spoilage and extends food shelf life. As the nutrients concentration decreases, the exponential growth rate decreases and the growth rate of the cells started to be stationery.

\section{Toxicity test}

Extraction using organic solvent has raised an issue of toxicity for human use. Though the toxicity of residual solvents received serious concerns in pharmaceutical products (Medley et al., 2014), their toxicity effect on food should not be neglected. The residual methanol allowable limit is $3000 \mathrm{ppm}$ (Lee and Kim, 2015). Additionally, Lee and Kim (2015) and Li et al. (2008) suggested that extraction involving the usage of organic solvent should undergo proper pre-treatment such as redissolve in water, freeze-drying or drying under reduced pressure prior to application.

An effective antibacterial should have high selective toxicity, that imposes potent concentration against pathogens, and at the same time gives minimal effect to host and possesses stable chemical and physical properties (Taylor, 2013). Thus, toxicity test should be proposed in order to meet this requirement. Often, effective antibacterial such as quinones is toxic to human (Rodriguez et al., 2004).

European Food Safety Authority (EFSA) requires rigorous toxicological testing of these antibacterial agents, including metabolism and toxicokinetic, subchronic toxicity, reproductive and developmental toxicity, and genotoxicity. These batteries of tests, including in vitro and in vivo tests in animals and humans, can take years and involves enormous expenses before they can be completed to obtain approval, which makes the pursuit of antibacterial unprofitable (Davidson et al., 2015)

In most countries, marketing involving food with a natural antibacterial agent requires approval from regulatory agencies. Thus, natural antibacterial agents also have to undergo the toxicology test. General food safety legislation, maximum limits and other restrictions (e.g., acceptable daily intake and the no observed adverse effect level) on the use of specific additives are established based on their toxicological information. However, it is difficult to set a specific acceptable daily intake or no observed adverse effect level for natural compounds because of the variation of components among batches. In the United States, any direct food additive substance which does not have GRAS status under the Federal Food, Drug, and Cosmetic Act, is considered as not safe (marketed before October 15, 1994) under the Dietary Supplement Health and Education Act. In cases where there is no other regulatory authorisation, the safety of such ingredient/ compound must be established for premarket approval through the petition process. Thus, not only do naturally 
occurring antibacterial agents, for example, clove extract, cinnamon oil, or fermented whey, from commonly consumed plant or animal products create appealing food labels for consumers, they are also less likely to be subjected to the complex regulatory requirements and approval process for use in food compared with synthetic preservatives (Davidson et al., 2015).

There is a dire need for toxicity study of crude and partially purified extract before a further investigation into antibacterial in food application can be undertaken. Fractionation and purification may affect the production cost (Pinazo et al., 2016) as well as solvent toxicity (Capello et al., 2007).

There is currently a tendency to call for substituting the use of laboratory animals in toxicological tests due to the high costs and the animals' suffering as a result of the various tests. Parra et al. (2001) opted for Artemia salina because of the strong correlation coefficient between Artemia salina bioassay and in vivo test discovered while doing toxicity investigation using mice. Burci et al. (2018) used Artemia salina as preliminary screening before usage of albino mice for toxicological tests. Abedon et al. (2012) suggested the utilisation of wax moth larva (Galleria Mellon Ella) for evaluating the toxicity and efficacy of antibacterial agents. This new method is effective in reducing toxicity, and is more economical, compared with the use of rats, mice or rabbits.

$\mathrm{LD}_{50}$ and $\mathrm{LC}_{50}$ are usually used to measure the toxicity of a sample towards tested animals. $\mathrm{LD}_{50}$ is an abbreviation for a lethal dose, which a single dose of a sample is administered to a group of animals and kills $50 \%$ of them. The expression of the value is the weight of extract administered per $1 \mathrm{~kg}$ of body weight of animal tested. Meanwhile, $\mathrm{LC}_{50}$ is an abbreviation for the lethal concentration of a sample that kills $50 \%$ of animals tested. $\mathrm{LC}_{50}$ value is expressed as the concentration of extract in a volume of the carrier liquid, or part per million, per duration of hours, exposed to the animals. The toxicity measurement indicates by the lower value of $\mathrm{LD}_{50}$ or $\mathrm{LC}_{50}$, the higher the toxicity of the extract.

There are two types of toxicological tests which known as an acute toxicity and chronic toxicity tests. An acute toxicity test can be conducted by oral or dermal exposure, where the effect of the consumed dose on the body responses and internal organs can be monitored (Padilla-Camberos et al., 2013). According to Meyer et al. (1982), a tested sample is considered as toxic when $\mathrm{LC}_{50}$ value is at $\leq 1000 \mu \mathrm{g} / \mathrm{mL}$ of tested concentration.
While acute toxicity test is conducted by a single dose consumption of a sample extract prior to daily observation, chronic toxicity test required daily dosing or exposure to a tested animal within a stipulated time. Chronic effects may result after months of daily exposure (Bouzidi et al., 2011).

Measuring toxicity of an extract at various concentration may lead to sigmoid-curve graph because of binomial response for the dependent variable, in example for toxicity case, death or no death. The application of Probit Analysis will transform the sigmoid graph to a linear graph, and hence regression of the relationship between response and various concentration can be determined (Finney, 1952). For an experimental study with lack of sample amount or multifactor involved, $\mathrm{LC}_{50}$ and $\mathrm{LD}_{50}$ can be determined by applying Probit Analysis.

\section{Conclusion}

Growing demand for natural preservatives has increased the quest for antibacterial agents from plants whereby commonly discarded plant seed is an option to cater to this demand. Although various natural products have been utilised as antibacterial agents, many of them are still underutilised in food application. However, a researcher should possess overview information of available antibacterial testing method, toxicity and application of the plant seeds to control pathogens. This information will support the research by determining the suitability of test, the safety of the plant seed for consumption. Furthermore, it helps to find an antibacterial agent with higher potency against resistant bacteria and render a provision to food safety and security and Halal industry worldwide.

\section{Conflict of Interest}

There is no conflict of interest while preparing this manuscript.

\section{Acknowledgements}

This work was supported by the Malaysia Fundamental Research Grant Scheme (FRGS19-0410649 or FRGS/1/2018/STG04/UIAM/03/1) of Ministry of Higher Education Malaysia.

\section{References}

Abdullah, B.M. and Salimon, J. (2010). Toxicity study of Malaysian rubber (Hevea brasiliensis) seed oil as rats and shrimps tests. Asian Journal of Biochemistry, 5(1), 33-39. https://doi.org/10.3923/ ajb.2010.33.39 
Abedon, S.T., Chan, B.K., Coote, P.J., Desbois, A.P., Eastwood, D.C., Hyman, P., and Watkinson, S.C. (2012). Advances in Applied Microbiology. London: Elsevier Incorporation.

Adejuwon, A.O., Agbaje, E.O. and Idika, N. (2011). Antifungal and antibacterial activities of aqueous and methanolic root extracts of Carica papaya linn. (Caricaceae). International Research Journal of Microbiology, 2(8), 270-277.

Aguirre, J.S., González, A., Özçelik, N., Rodríguez, M.R. and García de Fernando, G.D. (2013). Modeling the Listeria innocua micropopulation lag phase and its variability. International Journal of Food Microbiology, 164(1), 60-69. https:// doi.org/10.1016/j.ijfoodmicro.2013.03.003

Al-habib, A., Al-saleh, E., Safer, A. and Afzal, M. (2010). Bactericidal effect of grape seed extract on methicillin-resistant Staphylococcus aureus (MRSA). The Journal of Toxicological Sciences, 35 (3), 357-364. https://doi.org/10.2131/jts.35.357

Alqudsi, S.G. (2014). Awareness and Demand for $100 \%$ Halal Supply Chain Meat Products. Procedia Social and Behavioral Sciences, 130, 167-178. https://doi.org/10.1016/j.sbspro.2014.04.021

Baker, C.N., Stocker, S.A., Culver, D.H. and Thornsberry, C. (1991). Comparison of the E Test to agar dilution, broth microdilution, and agar diffusion susceptibility testing techniques by using a special challenge set of bacteria. Journal of Clinical Microbiology, 29(3), 533-538. https:// doi.org/10.1128/JCM.29.3.533-538.1991

Biehle, J.R., Cavalieri, S.J., Saubolle, M.A. and Getsinger, L.J. (1994). Comparative evaluation of the E test for susceptibility testing of Nocardia species. Diagnostic Microbiology and Infectious Disease, 19(2), 101-110. https:// doi.org/10.1016/0732-8893(94)90120-1

Boulekbache-Makhlouf, L., Slimani, S. and Madani, K. (2013). Total phenolic content, antioxidant and antibacterial activities of fruits of Eucalyptus globulus cultivated in Algeria. Industrial Crops and Products, 41, 85-89. https://doi.org/10.1016/ j.indcrop.2012.04.019

Bouzidi, A., Mahdeb, N. and Kara, N. (2011). Toxicity studies of alkaloids of seeds of Datura stramonium and synthesis alkaloids in male rats. Journal of Medicinal Plants Research, 5(15), 3421-3431. Retrieved from http://www.academicjournals.org/ JMPR

Broniatowski, M., Flasiński, M. and Hąc-Wydro, K. (2015). Antagonistic effects of $\alpha$-tocopherol and ursolic acid on model bacterial membranes.
Biochimica et Biophysica Acta (BBA) Biomembranes, 1848(10), 2154-2162. https:// doi.org/10.1016/j.bbamem.2015.05.009

Brul, S. and Coote, P. (1999). Preservative agents in foods: Mode of action and microbial resistance mechanisms. International Journal of Food Microbiology, 50(1-2), 1-17. https:// doi.org/10.1016/S0168-1605(99)00072-0

Burci, L.M., da Silva, C.B., Rondon, J.N., da Silva, L.M., de Andrade, S.F., Miguel, O.G., Dias, J.D.F.G. and Miguel, M.D. (2018). Acute and subacute (28 days) toxicity, hemolytic and cytotoxic effect of Artocarpus heterophyllus seed extracts. Toxicology Reports, 6, 1304-1308. https://doi.org/10.1016/ j.toxrep.2018.02.006

Calo, J.R., Crandall, P.G., O'Bryan, C.A. and Ricke, S.C. (2015). Essential oils as antimicrobials in food systems - A review. Food Control, 54, 111-119. https://doi.org/10.1016/j.foodcont.2014.12.040

Cano-Campos, M.C., Díaz-Camacho, S.P., UribeBeltrán, M.J., López-Angulo, G., Montes-Avila, J., Paredes-López, O. and Delgado-Vargas, F. (2011). Bio-guided fractionation of the antimutagenic activity of methanolic extract from the fruit of Randia echinocarpa (Sessé et Mociño) against 1nitropyrene. Food Research International, 44(9), 3087-3093. https://doi.org/10.1016/ j.foodres.2011.08.006

Capello, C., Fischer, U. and Hungerbühler, K. (2007). What is a green solvent? A comprehensive framework for the environmental assessment of solvents. Green Chemistry, 9(9), 927. https:// doi.org/10.1039/b617536h

Carey, E. (2009). Using calculus to model the growth of L. plantarum bacteria. Undergraduate Journal of Mathematical Modeling: One + Two, 1(2), 1-11. https://doi.org/10.5038/2326-3652.1.2.2

Carroll, K.C., Glanz, B.D., Borek, A.P., Burger, C., Bhally, H.S., Henciak, S. and Flayhart, D. (2006). Evaluation of the BD Phoenix Automated Microbiology System for Identification and Antimicrobial Susceptibility Testing of Enterobacteriaceae. Journal of Clinical Microbiology, 44(10), 3506 - 3509. https:// doi.org/10.1128/JCM.00994-06

Cattelan, M.G., Castilhos, M.B.M.D, Sales, P.J.P. and Hoffmann, F.L. (2013). Antibacterial activity of oregano essential oil against foodborne pathogens. Nutrition and Food Science, 43(2), 169-174. https:// doi.org/10.1108/00346651311313544

CLSI. (2012). Performance standards for antimicrobial disk susceptibility tests - approved atandard. Wayne, 
PA, USA: Clinical and Laboratory Standars Institute

Cseke, L.J., Setzer, W.N., Vogler, B., Kirakosyan, A. and Kaufman, P.B. (2006). Traditional, analytical and preparative separations of natural products. In Cseke, L.J., Kirakosyan, A., Kaufman, P.B., Warber, S., Duke, J.A. and Brielmann, H.L. (Eds.). Natural Products from Plants. $2^{\text {nd }}$ ed., p. 263-317. Boca Raton, Florida: Taylor and Francis. https:// doi.org/10.1201/9781420004472.ch8

Das, K., Tiwari, R.K.S., and Shrivastava, D.K. (2010). Techniques for evaluation of medicinal plant products as antimicrobial agent: Current methods and future trends. Journal of Medicinal Plants Research, 4(2), 104-111. https://doi.org/10.5897/ JMPR09.030

Davidson, P.M, Cekmer, H.B., Monu, E.A. and Techathuvanan, C. (2015). The use of natural antimicrobials in food: an overview. In Taylor, T.M. (Ed.). Handbook of Natural Antimicrobials for Food Safety and Quality. $1^{\text {st }}$ ed., p. 1-27. Cambridge: Woodhead Publishing Limited. https:// doi.org/10.1016/B978-1-78242-034-7.00001-3

Fader, R.C., Weaver, E., Fossett, R., Toyras, M., Vanderlaan, J., Gibbs, D., Wang, A. and Thierjung, N. (2013). Multilaboratory Study of the Biomic Automated Well-Reading Instrument versus MicroScan WalkAway for Reading MicroScan Antimicrobial Susceptibility and Identification Panels. Journal of Clinical Microbiology, 51(5), 1548 - 1554. https://doi.org/10.1128/JCM.03088-12

Farajzadeh, Z., Shakerian, A., Rahimi, E. and Bagheri, M. (2020). Chemical, Antioxidant, Total Phenolic and Flavonoid Components and Antimicrobial Effects of Different Species of Quinoa Seeds. Egyptian Journal of Veterinary Sciences, 51(1), 4354. https://doi.org/10.21608/ejvs.2019.17122.1098

Finney, D.J. (1952). Probit analysis: a statistical treatment of the sigmoid response curve. Cambridge, UK: Cambridge University Press,

Gibson, M. (2012). Food Security-A Commentary: What Is It and Why Is It So Complicated? Foods, 1 (1), 18-27. https://doi.org/10.3390/foods1010018

Gowdhami, M., Sarkar, B.L., and Ayyasamy, P.M. (2014). Screening of Phytochemicals and Antibacterial Activity of Annona Squamosa Extracts. International Journal of Pharmaceutical Science Invention, 3(7), 30-39. https:// doi.org/10.1093/jac/dkv366

Gutierrez, J., Barry-Ryan, C. and Bourke, P. (2009). Antimicrobial activity of plant essential oils using food model media: efficacy, synergistic potential and interactions with food components. Food
Microbiology, 26(2), 142-150. https:// doi.org/10.1016/j.fm.2008.10.008

Hall, B.G., Acar, H., Nandipati, A. and Barlow, M. (2014). Growth rates made easy. Molecular Biology and Evolution, 31(1), 232-238. https:// doi.org/10.1093/molbev/mst187

Hansen, J.N. (1994). Nisin as a model food preservative. Critical Reviews in Food Science and Nutrition, 34 (1), 69-93. https:// doi.org/10.1080/10408399409527650

Harish Prashanth, K.V. and Tharanathan, R.N. (2007). Chitin/chitosan: modifications and their unlimited application potential - an overview. Trends in Food Science and Technology, 18(3), 117-131. https:// doi.org/10.1016/j.tifs.2006.10.022

Ilanko, P., McDonnell, P.A., van Vuuren, S. and Cock, I.E. (2019). Interactive antibacterial profile of Moringa oleifera Lam. extracts and conventional antibiotics against bacterial triggers of some autoimmune inflammatory diseases. South African Journal of Botany, 124, 420-435. https:// doi.org/10.1016/j.sajb.2019.04.008

Ingram, J. (2011). A food systems approach to researching food security and its interactions with global environmental change. Food Security, 3(4), 417-431. https://doi.org/10.1007/s12571-011-0149-9

Iturriaga, L., Olabarrieta, I. and Marañón, I.M.D. (2012). International Journal of Food Microbiology Antimicrobial Assays of Natural Extracts and Their Inhibitory Effect against Listeria innocua and Fish Spoilage Bacteria, after Incorporation into Biopolymer Edible Films. International Journal of Food Microbiology, 158(1), 58-64. https:// doi.org/10.1016/j.ijfoodmicro.2012.07.001

Jain, N., Shasany, A.K., Sundaresan, V., Rajkumar, S., Darokar, M.P., Bagchi, G.D., Gupta, A.K., Kumar, S. and Khanuja, S.P.S. (2003). Molecular diversity in Phyllanthus amarus assessed through RAPD analysis. Current Science, 85, 1454-1458.

Ji, L.-L., Luo, Y.-M., and Yan, G.-L. (2008). Studies on the antimicrobial activities of extracts from Eupatorium lindleyanum DC against food spoilage and food-borne pathogens. Food Control, 19, 9951001. https://doi.org/10.1016/j.foodcont.2007.10.007

Jorgensen, J.H., Barry, A.L., Traczewski, M.M., Sahm, D.F., McElmeel, M.L. and Crawford, S.A. (2000). Rapid Automated Antimicrobial Susceptibility Testing of andlt;emandgt; Streptococcus pneumoniaeandlt;/emandgt; by Use of the bioMerieux VITEK 2. Journal of Clinical Microbiology, 38(8), 2814-2818. https:// doi.org/10.1128/JCM.38.8.2814-2818.2000 
Jothy, S.L., Zakaria, Z., Chen, Y., Lau, Y.L., Latha, L.Y. and Sasidharan, S. (2011). Acute oral toxicity of methanolic seed extract of Cassia fistula in mice. Molecules, 16(6), 5268-5282. https:// doi.org/10.3390/molecules 16065268

Juneja, V.K., Dwivedi, H.P. and Yan, X. (2012). Novel natural food antimicrobials. Annual Review of Food Science and Technology, 3, 381-403. https:// doi.org/10.1146/annurev-food-022811-101241

Kanatt, S.R., Chander, R. and Sharma, A. (2010). Antioxidant and antimicrobial activity of pomegranate peel extract improves the shelf life of chicken products. International Journal of Food Science and Technology, 45(2), 216-222. https:// doi.org/10.1111/j.1365-2621.2009.02124.x

Kelly, M.T., Latimer, J.M. and Balfour, L.C. (1982). Comparison of three automated systems for antimicrobial susceptibility testing of gram-negative bacilli. Journal of Clinical Microbiology, 15(5), 902 - $\quad$ 905. https://doi.org/10.1128/JCM.15.5.902905.1982

Kelmanson, J.E., Jäger, A.K. and Van Staden, J. (2000). Zulu medicinal plants with antibacterial activity. Journal of Ethnopharmacology, 69(3), 241-246. https://doi.org/10.1016/S0378-8741(99)00147-6

Klancnik, A., Piskernik, S., Jersek, B. and Mozina, S.S. (2010). Evaluation of diffusion and dilution methods to determine the antibacterial activity of plant extracts. Journal of Microbiological Methods, 81(2), 121-126.

j.mimet.2010.02.004

Kothari, V. (2014). Working with Natural Products (Extracts): Certain Useful Suggestions to Avoid Trouble. American Association for Science and Technology, 1(2), 37-39.

Lee, C.-G. and Kim, J.-H. Improved drying method for removal of residual solvents from paclitaxel by pretreatment with ethanol and water. Process Biochemistry, 50(6), 1031-1036. https:// doi.org/10.1016/j.procbio.2015.02.018

Li, M., Rouaud, O. and Poncelet, D. (2008). Microencapsulation by solvent evaporation: state of the art for process engineering approaches. International Journal of Pharmaceutics, 363(1-2), 26-39.

j.ijpharm.2008.07.018

López, S.N., Furlan, R.L.E. and Zacchino, S.A. (2011). Detection of antifungal compounds in Polygonum ferrugineum Wedd. extracts by bioassay-guided fractionation. Some evidences of their mode of action. Journal of Ethnopharmacology, 138(2), 633636. https://doi.org/10.1016/j.jep.2011.09.038
Lucera, A., Costa, C., Conte, A., and Del Nobile, M.A. (2012). Food applications of natural antimicrobial compounds. Frontiers in Microbiology, 3(August), 1 -13. https://doi.org/10.3389/fmicb.2012.00287

Lv, F., Liang, H., Yuan, Q. and Li, C. (2011). In vitro antimicrobial effects and mechanism of action of selected plant essential oil combinations against four food-related microorganisms. Food Research International, 44(9), 3057-3064. https:// doi.org/10.1016/j.foodres.2011.07.030

Macias, E.A., Mason Jr, E.O., Ocera, H.Y. and LaRocco, M.T. (1994). Comparison of E test with standard broth microdilution for determining antibiotic susceptibilities of penicillin-resistant strains of Streptococcus pneumoniae. Journal of Clinical Microbiology, 32(2), 430-432. https:// doi.org/10.1128/JCM.32.2.430-432.1994

Majhenič, L., Škerget, M. and Knez, Ž. (2007). Antioxidant and antimicrobial activity of guarana seed extracts. Food Chemistry, 104(3), 1258-1268. https://doi.org/10.1016/j.foodchem.2007.01.074

McGaw, L.J., Jager, A.K. and van Standen, J. (2002). Isolation of antibacterial fatty acids from Schotia brachypetala. Fitoterapia, 73(5), 431-433.

Medley, C.D., Kay, J., Li, Y., Gruenhagen, J., Yehl, P. and Chetwyn, N.P. (2014). Analytica Chimica Acta Quanti fi cation of residual solvents in antibody drug conjugates using gas chromatography. Analytica Chimica Acta, 850, 92-96.

Meyer, B., Ferrigni, N., Putnam, J., Jacobsen, L., Nichols, D. and McLaughlin, J. (1982). Brine Shrimp: A Convenient General Bioassay for Active Plant Constituents. Planta Medica, 45(5), 31-34. https://doi.org/10.1055/s-2007-971236

Mourey, A. and Canillac, N. (2002). Anti-Listeria monocytogenes activity of essential oils components of conifers. Food Control, 13(4-5), 289-292. https:// doi.org/10.1016/S0956-7135(02)00026-9

Orhan, D.D., Ozçelik, B., Ozgen, S. and Ergun, F. (2010). Antibacterial, antifungal, and antiviral activities of some flavonoids. Microbiological Research, 165(6), 496-504. https://doi.org/10.1016/ j.micres.2009.09.002

Orth, D.S. (1993). Handbook of cosmetic microbiology. New York, USA: Marcel Dekker, Inc.,

Osterburg, A., Gardner, J., Hyon, S.H., Neely, A. and Babcock, G. (2009). Highly antibiotic-resistant Acinetobacter baumannii clinical isolates are killed by the green tea polyphenol (-)-epigallocatechin-3gallate (EGCG). Clinical Microbiology and Infection, 15(4), 341-346. https://doi.org/10.1111/ j.1469-0691.2009.02710.x 
Othman, B.R., Kuan, C.H., Mohammed, A.S., Cheah, Y.K., Tan, C.W., New, C.Y., Thung, T.Y., Chang, W.S., Loo, Y.Y., Nakaguchi, Y., Nishibuchi, M. and Radu, S. (2018). Occurrence of methicillin-resistant Staphylococcus aureus in raw shellfish at retail markets in Malaysia and antibacterial efficacies of black seed (Nigella sativa) oil against MRSA. Food Control, 90, 324-331. https://doi.org/10.1016/ j.foodcont.2018.02.045

Othman, M., Loh, H.S., Wiart, C., Khoo, T.J., Lim, K.H. and Ting, K.N. (2011). Optimal methods for evaluating antimicrobial activities from plant extracts. Journal of Microbiological Methods, 84(2), 161-166. https://doi.org/10.1016/ j.mimet.2010.11.008

Padilla-Camberos, E., Martínez-Velázquez, M., FloresFernández, J.M. and Villanueva-Rodríguez, S. (2013). Acute toxicity and genotoxic activity of avocado seed extract (Persea americana Mill., c.v. Hass). The Scientific World Journal, 2013, 1-4. https://doi.org/10.1155/2013/245828

Parekh, J. and Chanda, S. (2011). Antibacterial and phytochemical studies on twelve species of Indian medicinal plants. African Journal of Biomedical Research, 10, 175-181. https://doi.org/10.4314/ ajbr.v10i2.50624

Parra, A.L., Yhebra, R.S., Sardiñas, I.G. and Buela, L.I. (2001). Comparative study of the assay of Artemia salina $\mathrm{L}$. and the estimate of the medium lethal dose (LD50 value) in mice, to determine oral acute toxicity of plant extracts. Phytomedicine, 8(5), 395400. https://doi.org/10.1078/0944-7113-00044

Pinazo, A., Manresa, M.A., Marques, A.M., Bustelo, M., Espuny, M.J. and Pérez, L. (2016). Amino acid based surfactants: New antimicrobial agents. Advances in Colloid and Interface Science, 228, 1739. https://doi.org/10.1016/j.cis.2015.11.007

Pykett, A.H. (1978). An assessment of the Sensititre method for determining minimum inhibitory and bactericidal concentrations. Journal of Clinical Pathology, 31(6), 536 - 538. https://doi.org/10.1136/ jcp.31.6.536

Qi, P., Hong, H., Liang, X. and Liu, D. (2009). Assessment of benzoic acid levels in milk in China. Food Control, 20(4), 414-418. https:// doi.org/10.1016/j.foodcont.2008.07.013

Rauha, J.-P., Remes, S., Heinonen, M., Hopia, A., Kahkonen, M., Kujala, T., Pihlaja, K., Vuorela, H. and Vuorela, P. (2000). Antimicrobial effects of Finnish plant extracts containing flavonoids and other phenolic compounds. International Journal of Food Microbiology, 56(1), 3-12. https:// doi.org/10.1016/S0168-1605(00)00218-X
Ríos, J.L. and Recio, M.C. (2005). Medicinal plants and antimicrobial activity. Journal of Ethnopharmacology, 100(1-2), 80-84. https:// doi.org/10.1016/j.jep.2005.04.025

Roccaro, A.S., Blanco, A.R., Giuliano, F., Rusciano, D. and Enea, V. (2004). Epigallocatechin-gallate enhances the activity of tetracycline in staphylococci by inhibiting its efflux from bacterial cells. Antimicrobial Agents and Chemotherapy, 48(6), 1968-1973. https://doi.org/10.1128/AAC.48.6.19681973.2004

Rodriguez, C.E., Shinyashiki, M., Froines, J., Yu, R.C., Fukuto, J.M. and Cho, A.K. (2004). An examination of quinone toxicity using the yeast Saccharomyces cerevisiae model system. Toxicology, 201(1-3), 185 -196. https://doi.org/10.1016/j.tox.2004.04.016

Rolfe, M.D., Rice, C.J., Lucchini, S., Pin, C., Thompson, A., Cameron, A.D.S., Alston, M., Stringer, M.F., Betts, R.P., Baranyi, J., Peck, M.W. and Hinton, J.C.D. (2012). Lag phase is a distinct growth phase that prepares bacteria for exponential growth and involves transient metal accumulation. Journal of Bacteriology, 194(3), 686-701. https:// doi.org/10.1128/JB.06112-11

Russell, A.D. (1991). Mechanisms of bacterial resistance to non-antibiotics: food additives and food and pharmaceutical preservatives. Journal of Applied Bacteriology, 71(3), 191-201. https:// doi.org/10.1111/j.1365-2672.1991.tb04447.x

Sani, M.S.A., Bakar, J., Rahman, R.A. and Abas, F. (2017). The antibacterial activities and chemical composition of extracts from Carica papaya cv . Sekaki / Hong Kong seed. International Food Research Journal, 24(April), 810-818.

Shaikh, T., Rub, R.A. and Sasikumar, S. (2016). Antimicrobial screening of Cichorium intybus seed extracts. Arabian Journal of Chemistry, 9 (Supplement 2), S1569-S1573. https:// doi.org/10.1016/j.arabjc.2012.04.012

Shee, A.K., Raja, R.B., Sethi, D., Kunhambu, A. and Arunachalam, K.D. (2010). Studies on the antibacterial activity potential of commonly used food preservatives. International Journal of Engineering Science and Technology, 2(3), 264-269.

Si, W., Gong, J., Tsao, R., Kalab, M., Yang, R. and Yin, Y. (2006). Bioassay-guided purification and identification of antimicrobial components in Chinese green tea extract. Journal of Chromatography A, 1125(2), 204-210. https:// doi.org/10.1016/j.chroma.2006.05.061

Snyder, J.W., Munier, G.K. and Johnson, C.L. (2008). Direct Comparison of the BD Phoenix System with 
the MicroScan WalkAway System for Identification and Antimicrobial Susceptibility Testing of Enterobacteriaceae and Nonfermentative GramNegative Organisms. Journal of Clinical Microbiology, 46(7), 2327 - $2333 . \quad \mathrm{https}: / /$ doi.org/10.1128/JCM.00075-08

Soni, R.R.S. and Bali, M. (2019). Evaluation of Antioxidant, Antimicrobial, and Antifungal Potential of Cucurbita Pepo Var . Fastigata Seed Extracts. Asian journal of Pharmaceutical and Clinical Research, 12(2), 289-293. https://doi.org/10.22159/ ajpcr.2019.v12i2.28040

Staneck, J.L., Vincelette, J., Lamothe, F. and Polk, E.A. (1983). Evaluation of the Sensititre system for identification of Enterobacteriaceae. Journal of Clinical Microbiology, 17(4), 647 LP - 654. Retrieved from http://jcm.asm.org/ content/17/4/647.abstract

Sunday, O.J., Babatunde, S.K., Ajiboye, A.E., Adedayo, R.M., Ajao, M.A. and Ajuwon, B.I. (2016). Evaluation of phytochemical properties and in-vitro antibacterial activity of the aqueous extracts of leaf, seed and root of Abrus precatorius Linn. against Salmonella and Shigella. Asian Pacific Journal of Tropical Biomedicine, 6(9), 755-759. https:// doi.org/10.1016/J.APJTB.2016.07.002

Tajkarimi, M.M., Ibrahim, S.A. and Cliver, D.O. (2010). Antimicrobial herb and spice compounds in food. Food Control, 21(9), 1199-1218. https:// doi.org/10.1016/j.foodcont.2010.02.003

Taylor, P.W. (2013). Alternative natural sources for a new generation of antibacterial agents. International Journal of Antimicrobial Agents, 42(3), 195-201. https://doi.org/10.1016/j.ijantimicag.2013.05.004

Torres, S., Pandey, A. and Castro, G.R. (2011). Organic solvent adaptation of Gram positive bacteria: applications and biotechnological potentials. Biotechnology Advances, 29(4), 442-452. https:// doi.org/10.1016/j.biotechadv.2011.04.002

Turgis, M., Dang, K., Dupont, C. and Lacroix, M. (2012). Combined antimicrobial effect of essential oils and bacteriocins against foodborne pathogens and food spoilage bacteria. Food Research International, 48(2), 696-702. https:// doi.org/10.1016/j.foodres.2012.06.016

Ullah, R., Nadeem, M., Khalique, A., Imran, M., Mehmood, S., Javid, A. and Hussain, J. (2016). Nutritional and therapeutic perspectives of Chia (Salvia hispanica L.): a review. Journal of Food Science and Technology, 53, 1750-1758. https:// doi.org/10.1007/s13197-015-1967-0

Upadhyay, A., Upadhyaya, I., Kollanoor-Johny, A. and
Venkitanarayanan, K. (2013). Antibiofilm effect of plant derived antimicrobials on Listeria monocytogenes. Food Microbiology, 36(1), 79-89. https://doi.org/10.1016/j.fm.2013.04.010

Vazirzadeh, M., Zaboli, J., Mohsenzadeh, S., Teixeira, J.S.D., Karbalaei-Heidari, H.R. and Robati, R. (2013). Antibacterial Activity of Ajowan (Trachyspermum copticum) Seed Extract. Medicinal and Aromatic Plant Science and Biotechnology, 7, 54-55.

Vigil, A.L.-M., Palou, E., Parish, M.E. and Davidson, P.M. (2005). Methods for activity assay and evaluation of results. In Micheal Davidson, P., Sofos, J.N. and Branen, A.L. (Eds.), Antimicrobials in Food. $3^{\text {rd }}$ ed. US: CRC Press.

Vikas, B., Nehru, J. and Botanic, T. (2013). Antibacterial activity of Annona squamosa seed extract. International Journal of Pharmacy and Technology, 5(3), 5651-5659.

Vladimir, M., Vukovi, N., Ni, N., Soluji, S., Mladenovi, M., Maškovi, P. and Stankovi, M.S. (2011). Studies on the antimicrobial activity and chemical composition of the essential oils and alcoholic extracts of Gentiana asclepiadea L . Journal of Medicinal Plants Research, 5(7), 1164-1174.

Wiegand, I., Hilpert, K. and Hancock, R.E.W. (2008). Agar and broth dilution methods to determine the minimal inhibitory concentration (MIC) of antimicrobial substances. Nature Protocols, 3(2), 163-175. https://doi.org/10.1038/nprot.2007.521

Wilson, A.E., Bergaentzlé, M., Bindler, F., Marchioni, E., Lintz, A. and Ennahar, S. (2013). In vitro efficacies of various isothiocyanates from cruciferous vegetables as antimicrobial agents against foodborne pathogens and spoilage bacteria. Food Control, 30(1), 318-324. https:// doi.org/10.1016/j.foodcont.2012.07.031

Wilson, R.K., Kwan, T.K., Kwan, C.-Y., and Sorger, G.J. (2002). Effects of papaya seed extract and benzyl isothiocyanate on vascular contraction. Life Sciences, 71(5), 497-507.

Yu, H.H., Song, M.W., Song, Y.J., Lee, N.K. and Paik, H.D. (2019). Antibacterial Effect of a Mixed Natural Preservative against Listeria monocytogenes on Lettuce and Raw Pork Loin. Journal of Food Protection, 82(11), 2001-2006. https:// doi.org/10.4315/0362-028X.JFP-19-026 